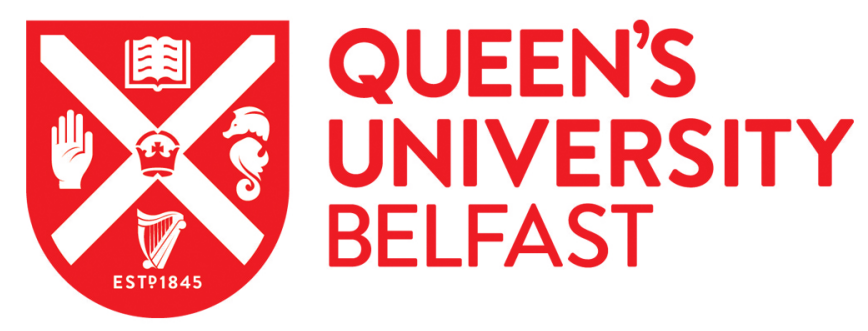

\title{
Relationship between Laves phase and the impact brittleness of P92 steel reevaluated
}

Zhong, W., Wang, W., Yang, X., Li, W., Yan, W., Sha, W., Wang, W., Shan, Y., \& Yang, K. (2015). Relationship between Laves phase and the impact brittleness of P92 steel reevaluated. Materials Science and Engineering A, 639, 252-258. https://doi.org/10.1016/j.msea.2015.05.012

Published in:

Materials Science and Engineering A

Document Version:

Peer reviewed version

Queen's University Belfast - Research Portal:

Link to publication record in Queen's University Belfast Research Portal

Publisher rights

(c) 2015, Elsevier. Licensed under the Creative Commons Attribution -NonCommercial-NoDerivs License

(https://creativecommons.org/licenses/by-nc-nd/4.0/), which permits distribution and reproduction for non-commercial purposes, provided the author and source are cited.

\section{General rights}

Copyright for the publications made accessible via the Queen's University Belfast Research Portal is retained by the author(s) and / or other copyright owners and it is a condition of accessing these publications that users recognise and abide by the legal requirements associated with these rights.

Take down policy

The Research Portal is Queen's institutional repository that provides access to Queen's research output. Every effort has been made to ensure that content in the Research Portal does not infringe any person's rights, or applicable UK laws. If you discover content in the Research Portal that you believe breaches copyright or violates any law, please contact openaccess@qub.ac.uk. 


\title{
Relationship between Laves phase and the impact brittleness of P92 steel reevaluated
}

Wanli Zhong ${ }^{1, *}$, Wei Wang ${ }^{1}, \mathrm{Xu}$ Yang $^{2}$, Wensheng $\mathrm{Li}^{1}$, Wei Yan ${ }^{3}$, Wei Sha ${ }^{4}$, Wei Wang ${ }^{3}$, Yiyin $\mathrm{Shan}^{3}, \mathrm{Ke}$ Yang $^{3, * *}$

${ }^{1}$ Electric Power Research Institute of Guangdong Power Grid Co., Ltd., Guangzhou 510080, China

${ }^{2}$ State Key Laboratory of Metastable Materials Science and Technology, Yanshan University, Qinhuangdao 066004, China

${ }^{3}$ Institute of Metal Research, Chinese Academy of Sciences, Shenyang 110016, China

${ }^{4}$ School of Planning, Architecture and Civil Engineering, Queen's University Belfast, Belfast BT9 5AG, UK

\begin{abstract}
Laves phase has been widely accepted to cause the impact brittleness of 9-12Cr martensitic heat-resistant steels after long time aging at elevated temperatures. However, in the present research, the impact toughness of the already brittle $\mathrm{P} 92$ steel aged at $600{ }^{\circ} \mathrm{C}$ for $2035 \mathrm{~h}$ could be restored to the original level by reheating at $700{ }^{\circ} \mathrm{C}$ for $1 \mathrm{~h}$, with Laves phase

\footnotetext{
* Corresponding author 1

Email address: zhongwanli@163.com

** Corresponding author 2
}

Email address: kyang@imr.ac.cn
\end{abstract}


barely changed. This interesting result strongly indicated that the presence of Laves phase might not be the real reason for the impact brittleness.

Keywords: steel; precipitation; fracture; mechanical characterization; electron microscopy; phase transformation

\section{Introduction}

In addition to $\mathrm{M}_{23} \mathrm{C}_{6}(\mathrm{M}$ is $\mathrm{Cr}$ and $\mathrm{Fe})$ carbides and $\mathrm{MX}(\mathrm{M}$ is $\mathrm{Nb}, \mathrm{V}$; $\mathrm{X}$ is $\mathrm{C}$ and/or $\mathrm{N})$ carbonitrides ${ }^{[1-4]}$, Laves phase, usually chemically recognized as $\mathrm{Fe}_{2}(\mathrm{~W}, \mathrm{Mo})$ with a complex hexagonal lattice, is another crucial precipitate in 9-12Cr martensitic heat-resistant steels. Laves phase contributes to creep resistance at the beginning by acting as obstacles to the dislocation movement and the grain or the subgrain migration ${ }^{[5]}$. However, it grows so fast that it soon becomes harmful to the creep strength ${ }^{[6,7]}$.

As well as creep strength, impact toughness is another important issue for safety of structural steels. A good understanding of the degradation behavior of impact toughness is critical to the safety of structures. Up to now, it has been generally believed that Laves phase is responsible for the impact brittleness of 9-12Cr martensitic heat-resistant steels after long-term aging at elevated temperatures ${ }^{[8-10]}$. The earliest report could be traced back to the work of Hosoi and coworkers $^{[11,12]}$, in which Laves phase was revealed to bring impact brittleness in a $9 \mathrm{Cr}-2 \mathrm{Mo}$ ferritic-martensitic steel because the absorbed energy upon impact decreased and the 
ductile-brittle transition temperature (DBTT) increased as the Laves phase started to precipitate. Kunimitsu et al. reported this phenomenon in $9 \mathrm{Cr}-2 \mathrm{~W}, 9 \mathrm{Cr}-2 \mathrm{Mo}$ and $9 \mathrm{Cr}-4 \mathrm{~W}$ steels ${ }^{[12]}$. Li has well reviewed this subject in his article ${ }^{[13]}$. In general, a conclusion can be drawn from all the above reports that impact brittleness happens when Laves phase forms during aging. This opinion has also seemed to be strongly supported from other angles. The first case is that the Si reduction from 0.67 to 0.008 in wt.\% was found to strongly postpone the formation of Laves phase ${ }^{[1,14]}$ and there was almost no change in the impact properties of the Si-free steel (with no Laves phase) when the aging time was increased from $1000 \mathrm{~h}$ to $2000 \mathrm{~h}$ at $600^{\circ} \mathrm{C}$, which implied that the impact brittleness would not occur if there was no Laves phase formation. The second case is that the impact brittleness could be eliminated by the Laves phase dissolution. Hosoi et al. ${ }^{[11]}$ reported that the decreased toughness could be recovered by reheating the steel at $775^{\circ} \mathrm{C}$ for only $1 \mathrm{~h}$. After this reheating, carbides still remained but the Laves phase was dissolved due to the low solvus of around $720{ }^{\circ} \mathrm{C}$ in $\mathrm{P} 92$ steel ${ }^{[15]}$. Another similar work ${ }^{[16]}$ showed that the impact toughness could be recovered even by reheating at a relatively low temperature of $720{ }^{\circ} \mathrm{C}$ for a long time of $200 \mathrm{~h}$. These two cases illustrate that the Laves phase could dissolve into matrix by reheating at either higher temperatures for a short time or lower temperatures for a long time, and the impact brittleness would be consequently removed.

The morphological characteristics of Laves phase that play critical roles in the impact brittleness have also been investigated. The research of Komazaki et al. ${ }^{[16]}$ showed that the 
drop in impact toughness was in poorer correlation with maximum size or number density of Laves phase, but uniquely correlated with an increase in the area fraction. Although the area fraction of Laves phase exhibited a fairer correlation with absorbed energy, the results still showed some scattering. In another work ${ }^{[17]}$, the decreased volume fraction of Laves phase was corresponding to the increased impact toughness. Both the area fraction and the volume fraction are basically the combination of particle size and number density. It appears that either of these two morphological characteristics could be regarded as the key factor that controls the impact brittleness and this could be well interpreted by the traditional fracture theory ${ }^{[16,17]}$.

These researches seem completed in both experimental and theoretical aspects. However, the present research shows that the impact toughness of the already brittle steel aged at $600{ }^{\circ} \mathrm{C}$ for $2035 \mathrm{~h}$ could also be restored by reheating only at $700^{\circ} \mathrm{C}$ for $1 \mathrm{~h}$ with the Laves phase barely changed. This result totally disagreed with the previous results, indicating that the impact brittleness could not be (solely) attributed to the presence of Laves phase. Thus, it seems that we are not truly clear about the effect of Laves phase on the impact toughness and further work should be done.

\section{Experimental}


The chemical composition of the P92 steel is shown in Table 1. The steel was normalized at $1050{ }^{\circ} \mathrm{C}$ for $50 \mathrm{~min}$ and then tempered at $760{ }^{\circ} \mathrm{C}$ for $1.5 \mathrm{~h}$, which produced a microstructure of tempered martensite before thermal exposure. The impact toughness of the samples aged at $600{ }^{\circ} \mathrm{C}$ for $500 \mathrm{~h}, 2035 \mathrm{~h}$, and $4200 \mathrm{~h}$ is presented in this paper to illustrate the aging induced impact brittleness. The already brittle samples were cut from the plate aged at $600{ }^{\circ} \mathrm{C}$ for $2035 \mathrm{~h}$ and then reheated at $700{ }^{\circ} \mathrm{C}$ for $0.5,1,4,6 \mathrm{~h}$.

Table 1. Chemical composition of the P92 experimental steel (wt. \%)

\begin{tabular}{llllllllll}
\hline $\mathrm{C}$ & $\mathrm{Cr}$ & $\mathrm{W}$ & $\mathrm{Mo}$ & $\mathrm{Mn}$ & $\mathrm{Si}$ & $\mathrm{V}$ & $\mathrm{Nb}$ & $\mathrm{S}$ & $\mathrm{P}$ \\
\hline 0.11 & 8.77 & 1.73 & 0.42 & 0.46 & 0.37 & 0.17 & 0.057 & 0.005 & 0.019 \\
\hline
\end{tabular}

Charpy V-notch $(\mathrm{CVN})$ impact specimens with the dimensions of $10 \times 10 \times 55 \mathrm{~mm}^{3}$ were used to evaluate the impact toughness of the aged and the reheated samples. All the impact tests were conducted at ambient temperature and the absorbed energy upon impact reported was the average of three specimens. The microstructures and the morphologies of the Laves phase after thermal aging and reheating were characterized by scanning electron microscopy (SEM) and transmission electron microscopy (TEM). The fractography of these specimens were conducted under SEM. The brittle broken impact specimens were cut into two halves perpendicular to the fracture surface, as illustrated in Fig. 1. The area near the fracture surfaces of the broken brittle impact specimens was examined by SEM to demonstrate the contribution of precipitates to cracking. 


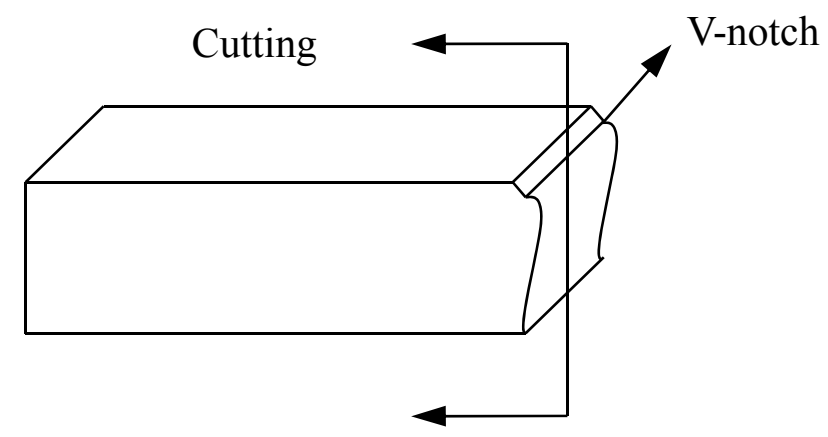

Fig. 1. Cutting the broken impact specimen into two halves in the middle.

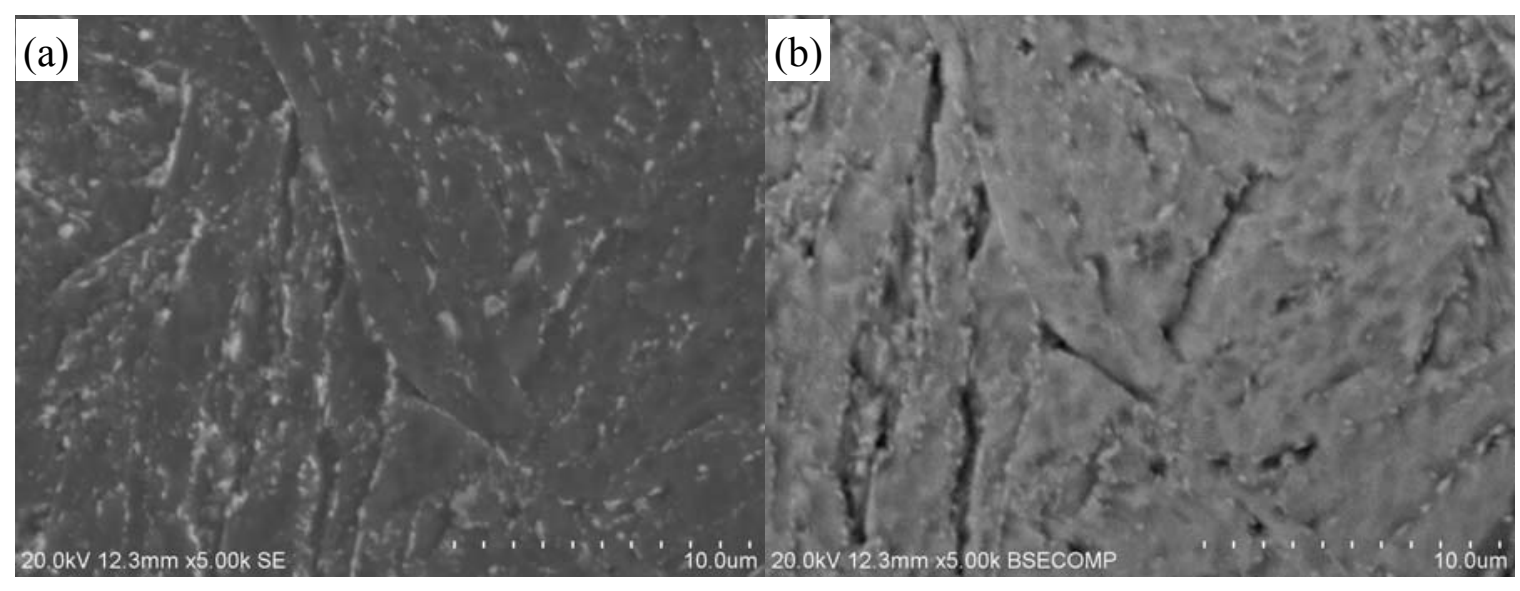

Fig. 2. Microstructure of the as tempered P92 steel: (a) secondary electron image; (b) BSE image.

\section{Results and discussion}

\subsection{Laves phase during aging}

Under the back-scattered electron (BSE) condition, the Mo and/or W-rich Laves phase can be distinguished from the $\mathrm{Cr}$-rich $\mathrm{M}_{23} \mathrm{C}_{6}$ carbide ${ }^{[16]}$. The original microstructure of the $\mathrm{P} 92$ steel 
before thermal aging was the tempered martensite strengthened mainly by $\mathrm{Cr}$-rich $\mathrm{M}_{23} \mathrm{C}_{6}$ carbide, as shown in Fig. 2. No bright Mo and/or W-rich Laves phase was found there.
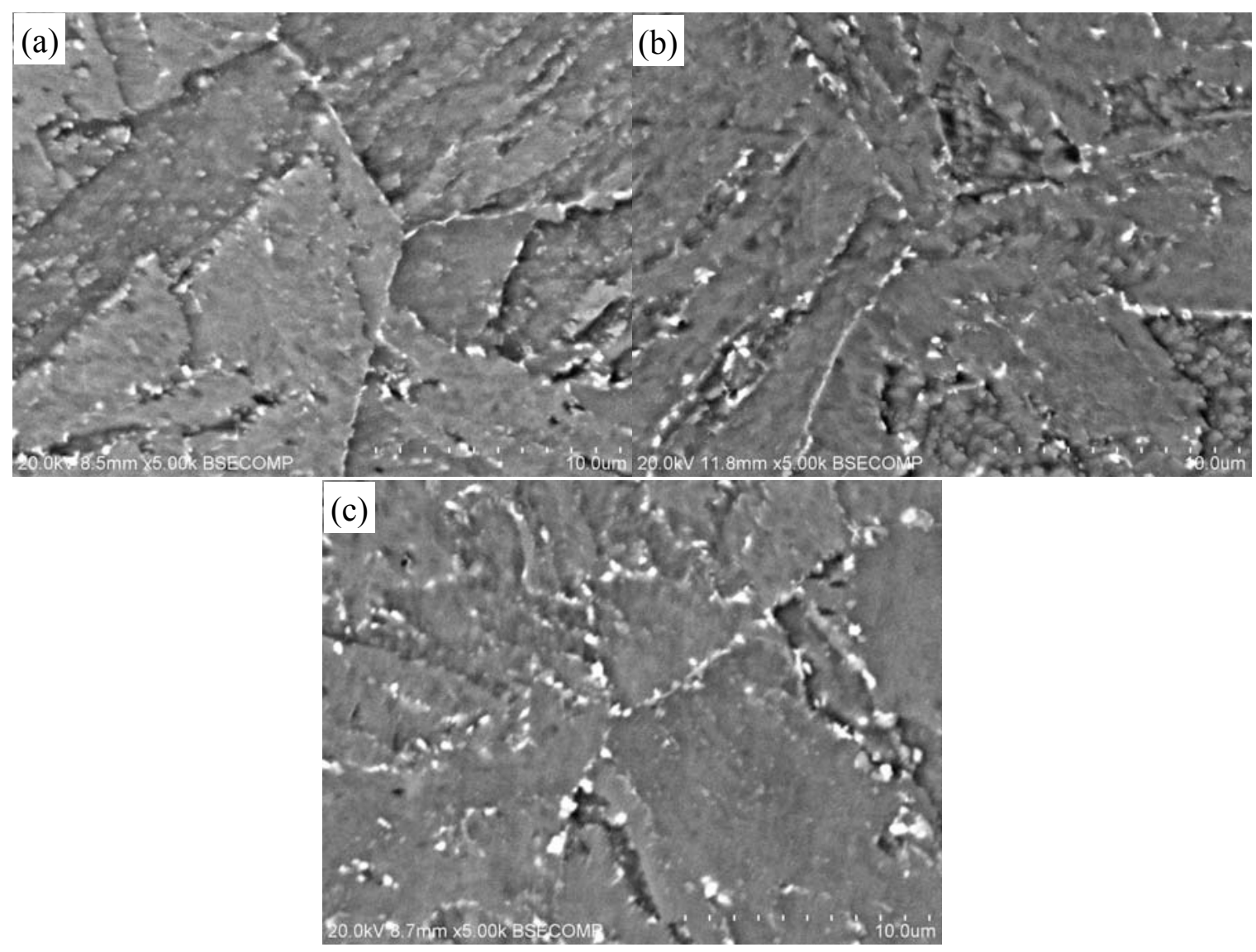

Fig. 3. BSE images of $\mathrm{P} 92$ steel aged at $600{ }^{\circ} \mathrm{C}$ for (a) $500 \mathrm{~h}$, (b) $2035 \mathrm{~h}$ and (c) $4200 \mathrm{~h}$.

The BSE images of the P92 steel aged at $600{ }^{\circ} \mathrm{C}$ for $500 \mathrm{~h}, 2035 \mathrm{~h}$ and $4200 \mathrm{~h}$ are given in

Fig. 3. Those bright white particles along grain boundaries and lath boundaries were identified as Mo and/or W-rich Laves phase. After aging at $600{ }^{\circ} \mathrm{C}$ for $500 \mathrm{~h}$, a good amount of Laves phase in the P92 steel was in rod like shape. According to the previous study ${ }^{[13]}$, this rod like shape illustrated that Laves phase was still coherent to the matrix. With the increase of the aging time, both the amount and the size of Laves phase were obviously 
increased, as displayed in Fig. 3b. The Laves phase was also observed to gradually change the shape from rod to block. After aging for $4200 \mathrm{~h}$, the largest size Laves phase has grown to nearly $1 \mu \mathrm{m}$; they should be completely incoherent to the matrix ${ }^{[15]}$.

\subsection{Impact brittleness after aging}

The impact toughness of the P92 steel was obviously reduced after thermal exposure. The absorbed energy upon impact dropped very quickly, from $154 \mathrm{~J}$ without aging to $69 \mathrm{~J}$ after aging at $600{ }^{\circ} \mathrm{C}$ for $500 \mathrm{~h}$. After then, the energy seemed stable with the increasing aging time. When the aging time was increased from $2035 \mathrm{~h}$ to $4200 \mathrm{~h}$, the absorbed energy upon impact was only decreased from $63 \mathrm{~J}$ to $52 \mathrm{~J}$.

The fracture morphology of the CVN specimens before and after aging at $600{ }^{\circ} \mathrm{C}$ is shown in Fig. 4. As demonstrated, the brittle quasi-cleavage area became larger while the ductile area smaller with the increase of aging time, which matched the impact toughness change well. As we can see in Fig. 4d, the cleavage area almost covered the whole fracture surface, which indicates the lowest absorbed energy upon impact.

\subsection{Impact toughness recovery after reheating}


The impact toughness was quickly restored after reheating at $700{ }^{\circ} \mathrm{C}$, returning to 84,142 , 128 and $117 \mathrm{~J}$ after reheating for $0.5,1,4,6 \mathrm{~h}$, respectively. The aging time before reheating was $2035 \mathrm{~h}$, as given in Section 2. When the reheating time was $1 \mathrm{~h}$, the impact toughness could be recovered to the originally high level. However, when the holding time was $0.5 \mathrm{~h}$, the impact toughness was partially restored and reached half of the original level. This indicates that the toughness recovery is attributed to a kinetic process. The thermodynamic condition could be satisfied by the reheating temperature of $700{ }^{\circ} \mathrm{C}$ and the kinetic condition would need time of $1 \mathrm{~h}$.
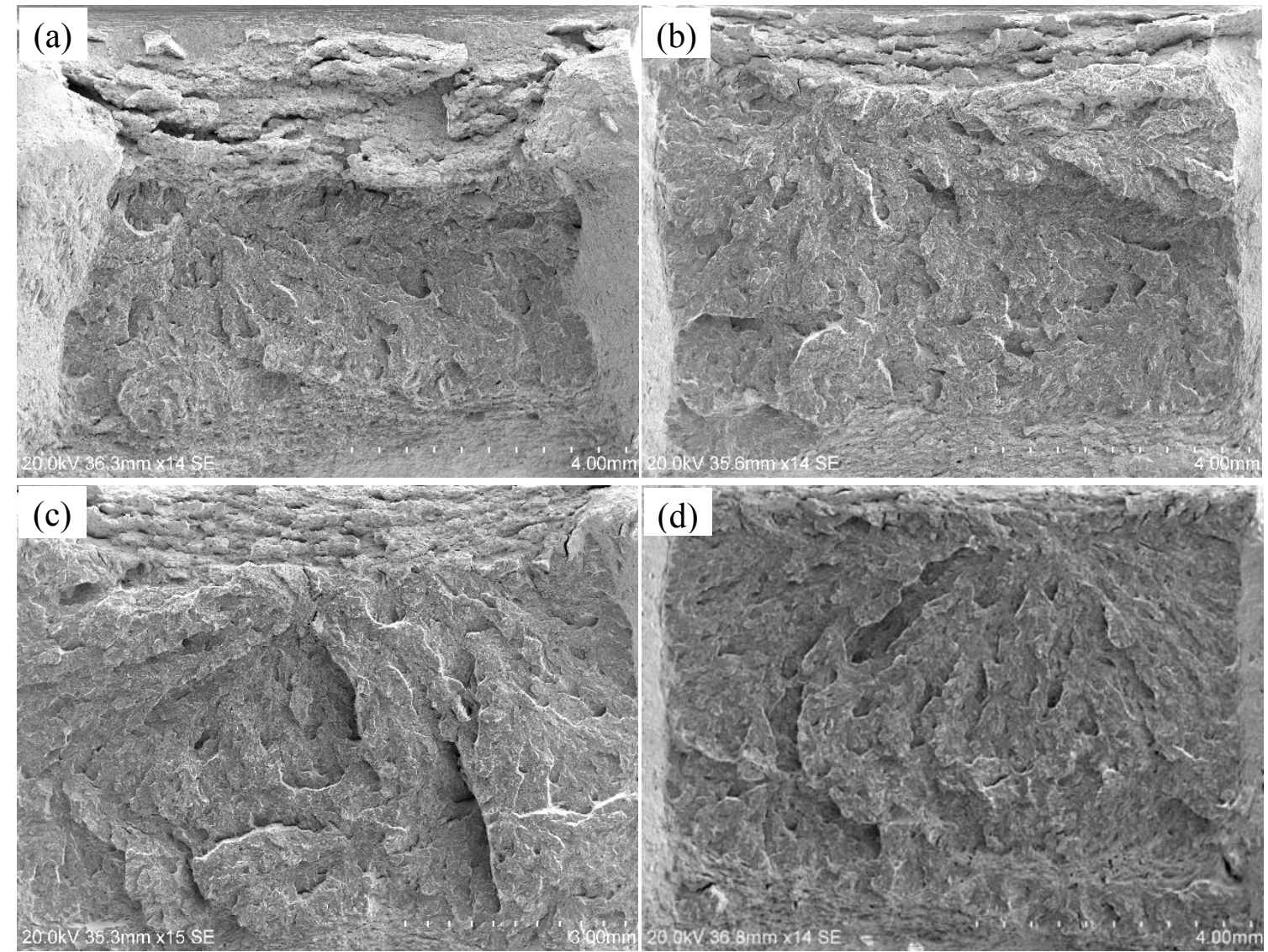

Fig. 4. Fractographs of $\mathrm{P} 92$ steel aged at $600{ }^{\circ} \mathrm{C}$ for (a) $0 \mathrm{~h}$, (b) $500 \mathrm{~h}$, (c) $2035 \mathrm{~h}$ and (d) 
The fracture morphologies of the specimens reheated for $0.5 \mathrm{~h}$ and $6 \mathrm{~h}$ are typically as shown in Fig. 5. The fracture characteristics of the reheated specimen at $700{ }^{\circ} \mathrm{C}$ for $0.5 \mathrm{~h}$ in Fig. 5a are similar to that of the as heat-treated specimen in Fig. 4a. The proportions of ductile area and cleavage area on the broken surface in both cases are almost the same. However, the absorbed energy of the former is only half of the latter. This could be understood in the way that although the ductile areas are almost the same, the ability of the matrix absorbing energy was different. The specimen insufficiently reheated at $700{ }^{\circ} \mathrm{C}$ for $0.5 \mathrm{~h}$ still cannot absorb energy as high as the as heat-treated specimen. The uncompleted recovering process only partially restored the matrix. The energy needed for breaking the matrix is not as high as for the original heat-treated matrix. Fig. 5b shows the fracture morphologpy of the broken specimen reheated at $700{ }^{\circ} \mathrm{C}$ for $6 \mathrm{~h}$, which represents the fracture morphology of all other fully recovered broken specimens and is corresponding with the high impact toughness.

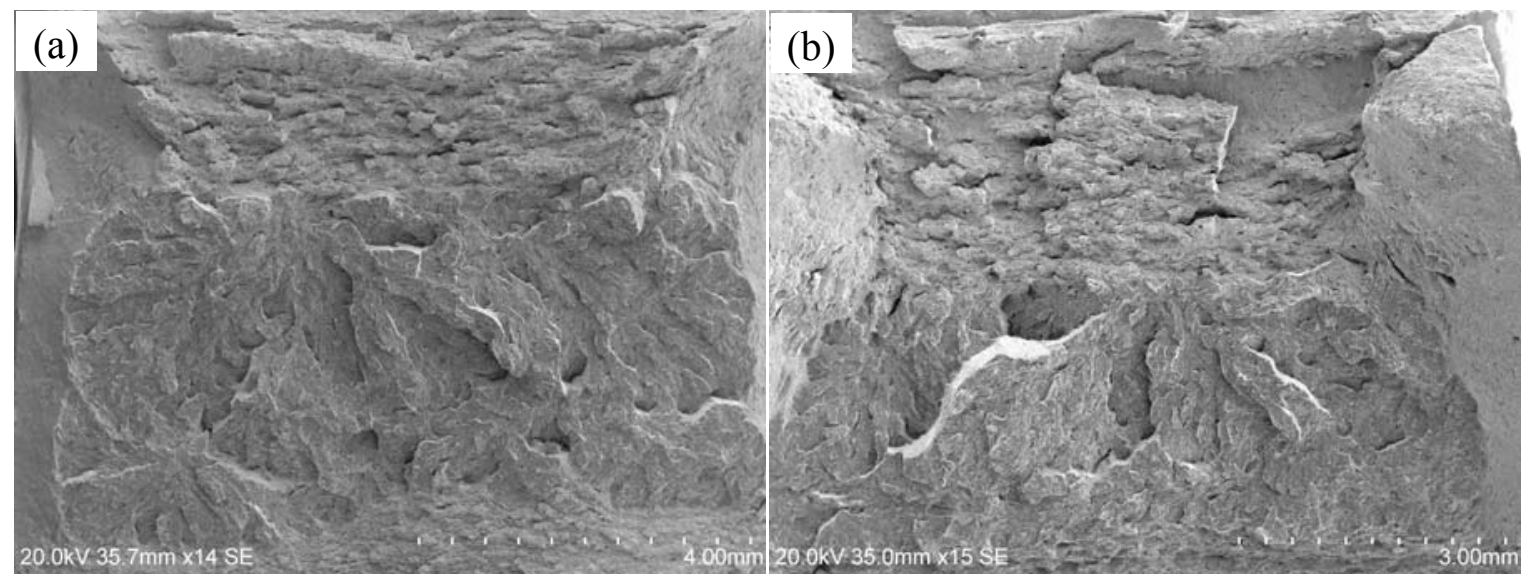

Fig. 5. Fractographs of the CVN specimens reheated at $700{ }^{\circ} \mathrm{C}$ for (a) $0.5 \mathrm{~h}$, (b) $6 \mathrm{~h}$. 

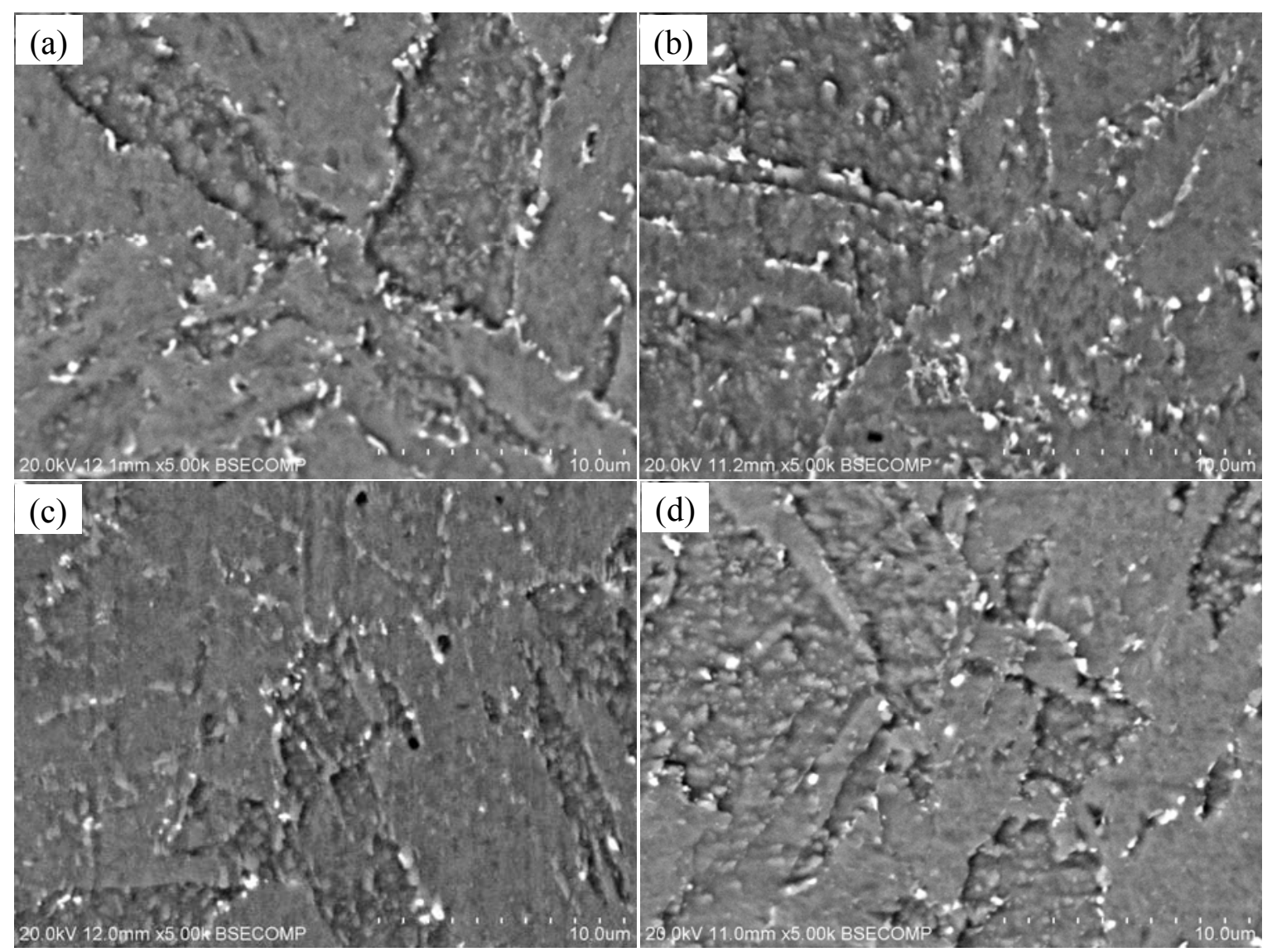

Fig. 6. Laves phase in the CVN specimens reheated at $700{ }^{\circ} \mathrm{C}$ for (a) $0.5 \mathrm{~h}$, (b) $1 \mathrm{~h}$, (c) $4 \mathrm{~h}$, (d)

$6 \mathrm{~h}$.

\subsection{Morphology of Laves phase after reheating}

The morphology of Laves phase after reheating at $700{ }^{\circ} \mathrm{C}$ for different times, under SEM, is

shown in Fig. 6. Compared with the morphology before reheating in Fig. 3b, the Laves phase

in Fig. 6a and $\mathrm{b}$ has no difference either in size or in number density. However, when the

reheating time is increased to 4 and $6 \mathrm{~h}$, the Laves phase seems to show a decrease in number

density, as illustrated in Fig. 6c and d. It seems to suggest that the temperature of $700{ }^{\circ} \mathrm{C}$ is

slightly higher than the solvus of the Laves phase in this P92 steel, so the amount of Laves 
phase was reduced when the reheating time was increased. The interesting finding is that the Laves phase was still in these reheated specimens under these reheating conditions, but these specimens had high impact toughness.

\subsection{Laves phase and impact brittleness}

The effect of the morphology evolution of Laves phase on the impact toughness has been widely interpreted according to the following equation ${ }^{[16,17]}$ :

$$
\sigma_{\mathrm{F}}=\left(\frac{\pi \mathrm{E} \gamma_{\mathrm{pm}}}{\left(1-v^{2}\right) \mathrm{a}}\right)^{1 / 2}
$$

where $\sigma_{\mathrm{F}}$ is the fracture stress, $\mathrm{E}$ is the Young's modulus, $\gamma_{\mathrm{pm}}$ is the effective surface energy, $v$ is the Poisson's ratio and a is the size of precipitates. This theory has been frequently used to describe the fracture behavior that is related to precipitates. This theory has also been used to explain the effect of Laves phase on the impact toughness of 9-12Cr heat-resistant steels.

However, in the present research, as shown in Fig. 3b and Fig. 6b, the Laves phase with the similar morphology leads to distinctly different impact toughness. An interesting conclusion could be reached from this result that the presence of Laves phase does not inevitably lead to the reduction of absorbed energy upon impact. The impact brittleness of 9-12Cr heat-resistant steels is not the necessary consequence of Laves phase. Comparing Fig. $6 \mathrm{~b}$ with $\mathrm{c}$ and $\mathrm{d}$, it could also be deduced that even when the number density of Laves phase is reduced, the 
impact toughness is stable, but not improved. This result is quite contrary to the widely accepted conventional opinion that Laves phase is the cause of impact brittleness.

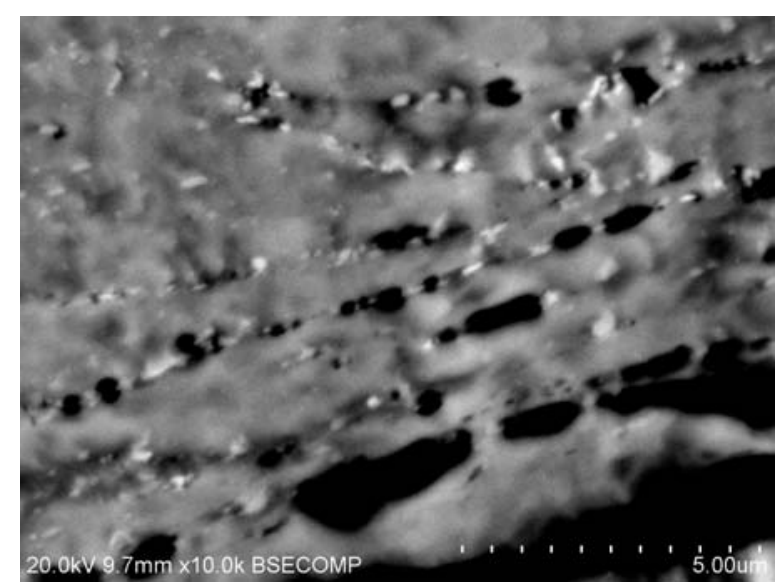

Fig. 7. BSE image showing crack along lath boundaries in the $\mathrm{CVN}$ specimen aged at $600{ }^{\circ} \mathrm{C}$ for $500 \mathrm{~h}$.

In order to understand the effect of precipitates on crack propagation during impact, the area near the fracture surface of the broken impact specimens was carefully observed under SEM. As shown in Fig. 7, in the brittle CVN specimen aged at $600^{\circ} \mathrm{C}$ for $500 \mathrm{~h}$, the martensitic laths were torn open during the deformation along the boundaries where the rod like Laves phase and $\mathrm{M}_{23} \mathrm{C}_{6}$ carbides were distributed. Laves phase seemed to weaken the adhesion of boundaries and facilitate the crack propagation. However, the similar phenomenon has also been found in the $\mathrm{CVN}$ specimens reheated at $700{ }^{\circ} \mathrm{C}$ for $1 \mathrm{~h}$. The Laves phase and $\mathrm{M}_{23} \mathrm{C}_{6}$ carbides were both observed to assist crack propagation along the martensitic lath boundaries, as shown in Fig. 8a. Even without Laves phase, $\mathrm{M}_{23} \mathrm{C}_{6}$ carbides showed the same behavior during the deformation in the original tempered specimens, as shown in Fig. 8b. Therefore, it 
seems that the Laves phase is not solely responsible for impact fracture behavior in particular brittleness, though it does assist crack propagation.

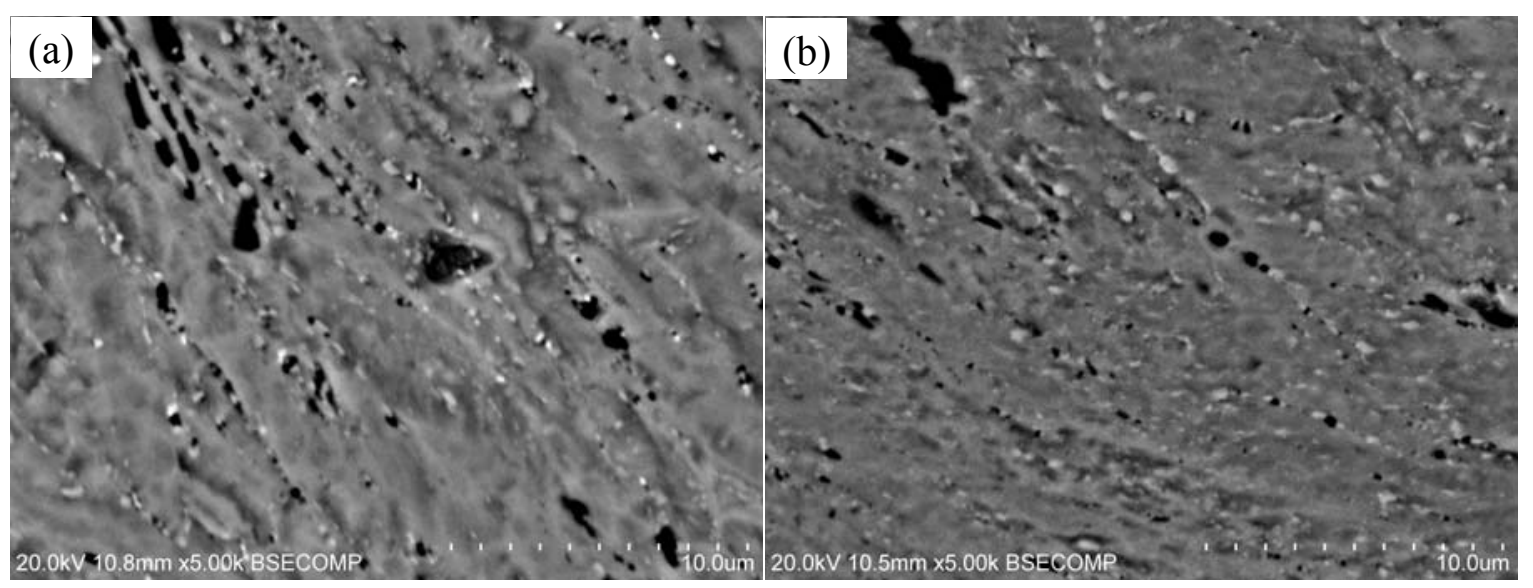

Fig. 8. BSE images showing cracks along lath boundaries in the CVN specimens: (a) reheated at $700{ }^{\circ} \mathrm{C}$ for $1 \mathrm{~h}$; (b) original tempered at $760{ }^{\circ} \mathrm{C}$ for $1.5 \mathrm{~h}$.

Investigation to find out the consequence that reheating brought about to the microstructure of the already brittle CVN specimen aged at $600{ }^{\circ} \mathrm{C}$ for $2035 \mathrm{~h}$ has also been carried out on the specimen reheated at $700{ }^{\circ} \mathrm{C}$ for $1 \mathrm{~h}$ under TEM. Under these two conditions, the microstructures under TEM are quite the same. As shown in Fig. 9a and b, the matrices were both the evolved martensitic laths and there are precipitates including Laves phase and $\mathrm{M}_{23} \mathrm{C}_{6}$ carbides along lath boundaries. The Laves phase in them is both around $0.5 \mu \mathrm{m}$ and could be connected together, as shown in Fig. 9c and d. Under TEM, no remarkable microstructure difference could be found to possibly correspond to the impact brittleness. 

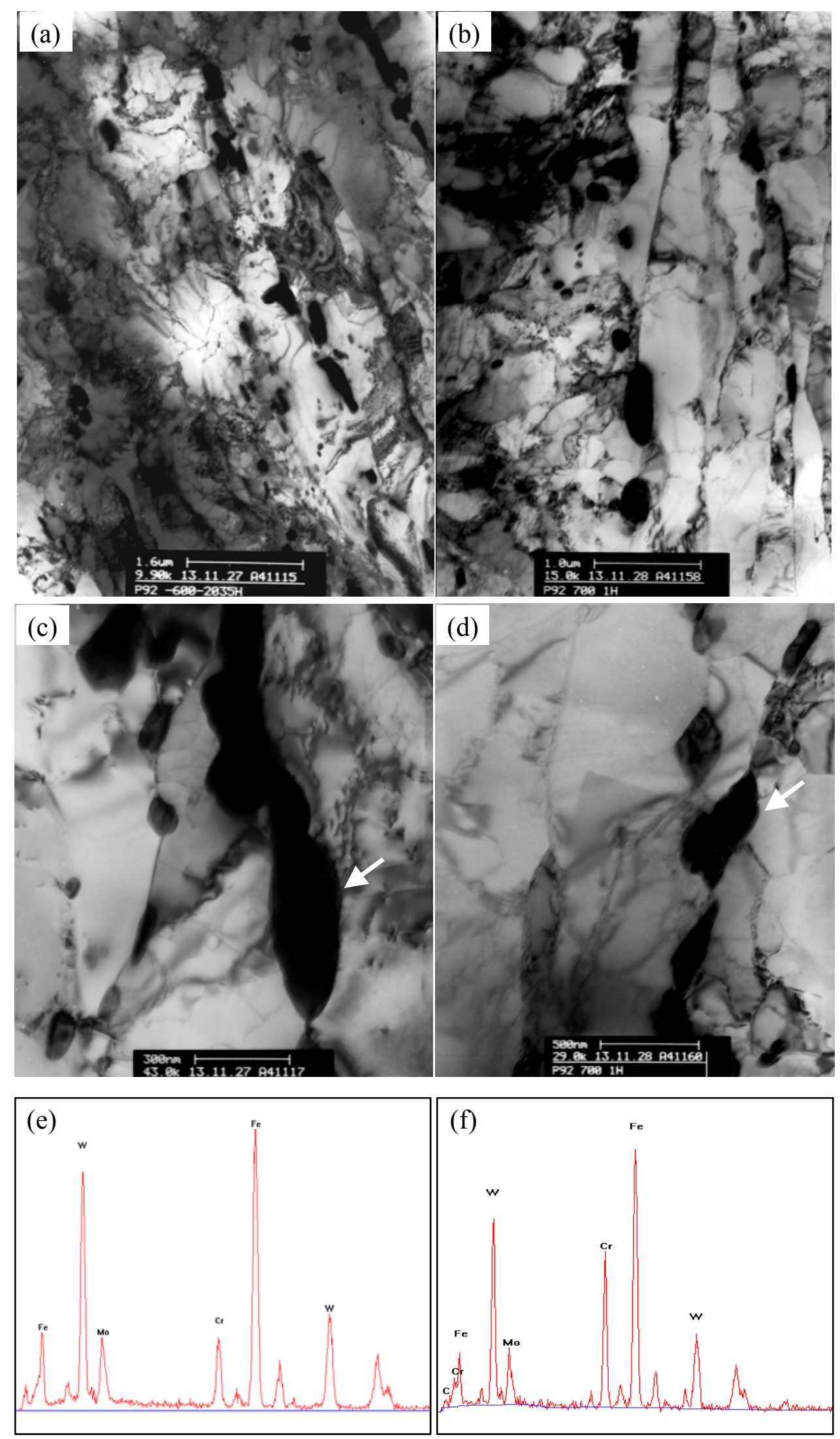

Fig. 9. TEM images and energy dispersive X-ray spectra of Laves precipiates showing the microstructure and the Laves phase in the impact specimens: (a), (c), (e) aged at $600{ }^{\circ} \mathrm{C}$ for $2035 \mathrm{~h}$; (b), (d) (f) reheated at $700{ }^{\circ} \mathrm{C}$ for $1 \mathrm{~h}$. 
Till now, it may be concluded that removing the Laves phase is not necessary for removing the impact brittleness. Further work is being carried out to find the real cause, other than Laves phase or such characters as the size and the number density of Laves phase, that are responsible for the impact brittleness of P92 steel during aging. Some more specific structural characteristics such as the difference of the interfacial energy between the incoherent Laves phase and the coherent Laves phase and the matrix ${ }^{[15]}$ might be a lead for the further research.

\subsection{Discussion on the Laves composition and morphology}

The effect of the heat treatment on the Laves composition and morphology is discussed in this section. The effect of elements on kinetics, composition and morphology of the Laves phase was included in previous studies ${ }^{[18-20]}$.

In particular, the effect on mechanical properties observed should be related to a combination of effects. Fig. 9 shows the characterization of the Laves phase after tempering and reheating. As observed, there is a change of the Cr signal in the Laves phase composition from the EDX-TEM analysis, which is similar to the observation in the references ${ }^{[18-19]}$. This has a consequence on depletion of $\mathrm{Cr}$ but also on change of the $\mathrm{W}$ content in the matrix of the steel. 
Previous research ${ }^{[18-20]}$ also provides some basis for the effect of heat treatment on morphology, in particular if we are dealing with newly nucleated Laves phase or re-transformed Laves phase on grain boundaries. From the microstructure observation in the present work, it appears inconceivable for the Laves phase after reheating to be all newly nucleated, though a fraction of it could be re-transformed.

There is a role of $\mathrm{M}_{23} \mathrm{C}_{6}$ carbides in combination with the Laves phase, since it has been demonstrated that the presence of both phases are competitive (diffusion controlled) in both microstructure formation and evolution, and mechanical properties.

\section{Conclusions}

The present research is concerned with the effect of Laves phase on impact brittleness. Some interesting conclusions have been reached.

(1) The absorbed energy upon impact of the already brittle specimens aged at $600{ }^{\circ} \mathrm{C}$ for $2035 \mathrm{~h}$ could be restored by reheating at $700{ }^{\circ} \mathrm{C}$ for $1 \mathrm{~h}$, with Laves phase having hardly changed in size or number density.

(2) The presence of Laves phase is not necessarily responsible for the impact brittleness. The formation of Laves phase has been widely accepted as the cause of the impact brittleness of 9-12Cr heat resistant steels. However, in the present research, even with 
the presence of Laves phase, the steel could still have high absorbed energy upon impact.

(3) Further work should be carried out to investigate the real reason for the impact brittleness of 9-12Cr heat resistant steels during aging.

\section{Acknowledgements}

This work was financially supported by The China Southern Power Grid Corp funded science and technology project (K-GD2014-162).

\section{References}

[1] J. Hald, Int. J. Press. Vessels Piping 85 (2008) 30-37.

[2] V. Sklenicka, K. Kucharovà, M. Svoboda, L. Kloc, J. Bursik, A. Kroupa, Mater. Charact. 51 (2003) 35-48.

[3] R.O. Kaybyshev, V.N. Skorobogatykh, I.A. Shchenkova, Phys. Met. Metall. 109 (2010) 186-200.

[4] A. Kipelova, R. Kaibyshev, A. Belyakov, D. Molodov, Mater. Sci. Eng. A 528 (2011) 1280-1286.

[5] P.J. Ennis, A. Zielinska-Lipiec, O. Wachter, A. Czyrska-Filemonowicz, Acta Mater. 45 (1997) 4901-4907.

[6] J.S. Lee, H.G. Armaki, K. Maruyama, T. Muraki, H. Asahi, Mater. Sci. Eng. A 428 (2006) 270-275.

[7] F. Abe, Metall. Mater. Trans. A 36 (2005) 321-332.

[8] L. Schäfer, J. Nucl. Mater. 283-287 (2000) 707-710.

[9] K. Yamamoto, Y. Kimura, Y. Mishima, ISIJ Int. 43 (2003) 1253-1259. 
[10] P. Fernández, M. Hernández-Mayoral, J. Lapeña, A.M. Lancha, G. De Diego.. Mater. Sci. Technol. 18 (2002) 13531362.

[11] Y. Hosoi, N. Wade, S. Kunimitsu, T. Urita, J. Nucl. Mater. 141-143 (1986) 461-467.

[12] S. Kunimitsu, Y. You, N. Kasuya, Y. Sasaki, Y. Hosoi, J. Nucl. Mater. 179-181 (1991) 689-692.

[13] Q. Li, Metall. Mater. Trans. A 37 (2003) 89-97.

[14] A. Aghajani, F. Richter, C. Somsen, S.G. Fries, I. Steinbach, G. Eggeler, Scr. Mater. 61 (2009) 1068-1071.

[15] J. Hald, L. Korcakova, ISIJ Int. 43 (2003) 420-427.

[16] S. Komazaki, S. Kishi, T. Shoji, H. Chiba, K. Suzuki, Mater. Sci. Res. Int. 9 (2003) 42-49.

[17] M.P. Sello, W.E. Stumpf, Mater. Sci. Eng. A 527 (2010) 5194-5202.

[18] O. Prat, J. Garcia, D. Rojas, C. Carrasco, G. Inden, Acta Mater. 58 (2010) 6142-6153.

[19] O. Prat, J. Garcia, D. Rojasc, G. Sauthoff, G. Inden, Intermetallics 32 (2013) 362-372.

[20] H. Cui, F. Sun, K. Chen, L. Zhang, R. Wan, A. Shan, J. Wu, Mater. Sci. Eng. A 527 (2010) 7505-7509. 